\title{
Isolating Stem Cells From Skin: Designing a Novel Highly Efficient Non-Enzymatic Approach
}

\author{
E. BELLU ${ }^{1}$, G. GARRONi ${ }^{1}$, F. BALZANO ${ }^{1}$, R. SATTA ${ }^{2}$, M. A. MONTESU ${ }^{2}$, \\ M. KRALOVIČ $\check{5}^{5.7}$, J. FEDAČKO ${ }^{6}$, S. CRUCIANI $^{1}$, M. MAIOLI ${ }^{1,3,4}$
}

${ }^{1}$ Department of Biomedical Sciences, University of Sassari, Sassari, Italy, ${ }^{2}$ Department of Medical, Surgical and Experimental Sciences, University of Sassari, Sassari, Italy, ${ }^{3}$ Center for Developmental Biology and Reprogramming- CEDEBIOR, Department of Biomedical Sciences, University of Sassari, Sassari, Italy, ${ }^{4}$ Institute of Genetic and Biomedical Research, National Research Council, Cagliari, Italy, ${ }^{5}$ Czech Technical University in Prague, University Centre for Energy Efficient Buildings, Buštěhrad, Czech Republic, ${ }^{6}$ Department of Medical and Clinical Biophysics, Faculty of Medicine, Pavol Jozef Šafárik University, Košice, Slovak Republic, ${ }^{7}$ Department of Biophysics, Second Faculty of Medicine, Charles University, Prague, Czech Republic

Received August 1, 2019

Accepted September 25, 2019

\begin{abstract}
Summary
Stem cells are undifferentiated elements capable to acquire a specific cellular phenotype under the influence of specific stimuli, thus being involved in tissue integrity and maintenance. In the skin tissue self-renewal and wound healing after injury is a complex process, especially in adulthood, due to the aging process and the continuous exposure to damaging agents. The importance of stem cells in regenerative medicine is well known and defining or improving their isolation methods is therefore a primary and crucial step. In the present paper we present a novel method to isolate stem cells from human skin, including the involvement of a novel medium for the maintenance and expansion of in vitro cultures. The biopsies were mechanically digested and put in culture. The migrating cells were positive selected with magnetic cell sorting, characterized by flowcytometry analysis, and viability detected by MTT assay. Cells exhibited a mesenchymal phenotype, as demonstrated by the positive acquirement of an osteogenic or adipogenic phenotype when cultured in specific conditioned media. Taken together our results disclose a novel method for culturing and expanding stem cells from skin and pave the way for future clinical applications in tissue regeneration.
\end{abstract}

\section{Key words}

Stem cells • Cell differentiation • Isolation technique

\section{Corresponding author}

M. Maioli, Department of Biomedical Sciences, University of Sassari, Sassari, Italy. E-mail: mmaioli@uniss.it

Stem cells are undifferentiated elements, able to reply to physical and chemical stimuli from the surrounding environment, by changing cell polarity, differentiation and senescence (Maioli et al. 2016). This particular cell-population is engaged in maintaining tissue integrity and replacing damaged elements (Rinaldi et al. 2014). Stem cells are located in the so called "stem cell niche", a protected milieu apparently conserved in different tissue and organisms. The position of stem cells in the niche allow them to remain quiescent until they are enrolled in differentiation or self-renewal processes, according to the specific requirements needed to retain tissue homeostasis (Mao et al. 2015, Quan and Fisher 2015). Stem cells can duplicate in two different ways in order to maintain their undifferentiated condition. The first one is a symmetric division which leads to the formation of two stem cells identical to the 'mother', the second one is an asymmetric process, in which one cell remain undifferentiated while the other undergo differentiation, with the two resulting cells exhibiting 
different features (Khavkin et al. 2011). The effectiveness of this process is deeply influenced by cell senescence, slowing down progressively (Maioli et al. 2014). An excellent example of this process takes place in the skin during wound healing after injury, a very complex process in which many pathways are activated to obtain a finely tuned response (Gurtner et al. 2008).

Skin is the largest organ of the human body and its primary function is to provide a protective barrier for the organism from the environmental injuries. This tissue consists of two different layers: the epidermidis and the dermis. The dermis, mainly composed by extra cellular matrix, synthetized by fibroblasts, is located between subcutaneous adipose tissue and epidermidis (Quan and Fisher 2015). In the epidermidis, the most external part, keratinocytes provide to the formation of stratum corneum full of insoluble bundles of keratine. Indeed, thanks to asymmetric division of stem cells in the basal stratus, mitotically derived cells undergo different fate: one of the cells preserve the undifferentiated status and remains in the basal layer niche; the second one migrates to the upper layers and differentiate, gradually acquiring a dead squames phenotype (Yousef et al. 2018).

When the tissue homeostasis is perturbated, extrinsic or intrinsic signals reaches skin stem cells, which may be recruited, becoming epidermal linages differentiated cells (Mao et al. 2015, Quan and Fisher 2015). In adulthood tissue self-renewal and wound healing are difficult processes. Aging affects skin more than any other organs since it is constantly exposed to injuries. Two different processes are involved in cutaneous aging: intrinsic aging, and extrinsic aging. Both of these processes result in a fibrotic tissue that become unable to exert some of the most important function of the skin (Gurtner et al. 2008). For these reasons skin stem cells, as well as stem cells coming from other tissues, represent an important resource for regenerative medicine studies (Maioli M. et al. 2013), being able to differentiate toward a specific phenotype, under selected stimuli. For example, stem cells isolated from Adipose tissue (Santaniello et al. 2018), Wharton jelly (Balzano et al. 2019), foetal membrane (Maioli et al. 2010) and other tissues have been largely described for their capability to give rise to many cellular lineages, even different from their original belonging tissue. Regenerative medicine is always challenging the discovery of novel safe and easily reliable systems, to implement stem cell regenerative capability.

Stem cells isolation from the skin have been described several years ago, but still represent a very low yield process obtained after intricate protocols based on mechanical separation and enzymatic digestions, which also significantly affect cell viability (da Silva Jeremias et al. 2014, Jeong-Ran et al. 2014).

Aim of the present manuscript is to describe a novel non-enzymatic method to isolate stem cells from human skin, by the aid of a specific novel culturing medium suitable for a high rate cell proliferation.

For cell isolation skin biopsies from male and female adult patients (12 samples) from the Dermatological Clinic, Department of Medical, Surgical and Experimental Sciences, in Sassari (Ethical Clearance N. 0021565/2018, 22/03/2018-Commissione Etica CNR) were collected in RPMI1640 (Lonza Bioscience) solution containing $100 \mathrm{U} / \mathrm{ml}$ penicillin, $100 \mu \mathrm{g} / \mathrm{ml}$ streptomycin (Invitrogen) ("Collecting medium" C-medium). Samples were reduced into small fragments of approximately $2 \mathrm{~mm} \times 4 \mathrm{~mm}$ in a petri dish by the aid of a sterile scalpels. Fragments of tissue were plated on the bottom of a $35 \mathrm{~mm}$ culture dishes, three to five pieces for each well with Specific Culture Medium (SC-medium): DMEM supplemented with $15 \%$ of fetal bovine serum (FBS) and $0.1 \mathrm{mM} \quad \beta$-mercaptoethanol (Life Technologies, Grand Island, NY, USA), $1 \%$ L-glutamine (Euroclone, Milano, Italy), $1 \%$ nonessential amino acids (Gibco), $200 \mathrm{U} / \mathrm{ml}$ penicillin and $0.1 \mathrm{mg} / \mathrm{ml}$ streptomycin, FGF (Gibco). Culture were transferred at $37{ }^{\circ} \mathrm{C} 5 \% \mathrm{CO}_{2}$ in a humidified atmosphere and medium was changed every 4 days.

One week after the isolation process cell migration could be observed under optical microscope (Leica ICC50 HD). Fragments waste were removed, and cell cultured till confluence, then transferred to T75 flasks (Euroclone, Italy).

The positive selection of stem cells from skin was obtained with magnetic cell sorting using a primary monoclonal anti-c/kit (CD117) antibody (Miltenyi Biotec, Minneapolis, MN, USA) and then cells were magnetically labelled in columns with a secondary antibody directly conjugated to MicroBeads (MACS Miltenyi Biotec, Bologna, Italy). The selected population was then prepared for the flow-cytometry analysis, according to previously described method (Basoli et al. 2017).

Cells showed positivity for all mesenchymal surface markers (CD73, CD90, CD105) and were negative for CD31 and CD45 (data not shown). Isolated cells exhibited a mesenchymal phenotype, since were 
able to differentiate into osteogenic and adipogenic phenotype (see previously described protocols Basoli et al. 2017), (Fig. 1) maintaining this feature also after freezing.

The cell growth curve was measured as indicator of cell proliferation. To define the usefulness of the SCmedium, skin stem cells at passage 1 were grown in this medium and another group of cells were maintained in a growth basic medium (BM) (DMEM supplemented with $10 \%$ FBS, $200 \mathrm{U} / \mathrm{ml}$ penicillin and $0.1 \mathrm{mg} / \mathrm{ml}$ streptomycin), considered as control. The number of cells/well was analysed every $24 \mathrm{~h}$, using Luna automatic cell counter. MTT assay was performed to test the metabolic activity of isolated cells in SC-Medium and the control BM (Fig. 2).

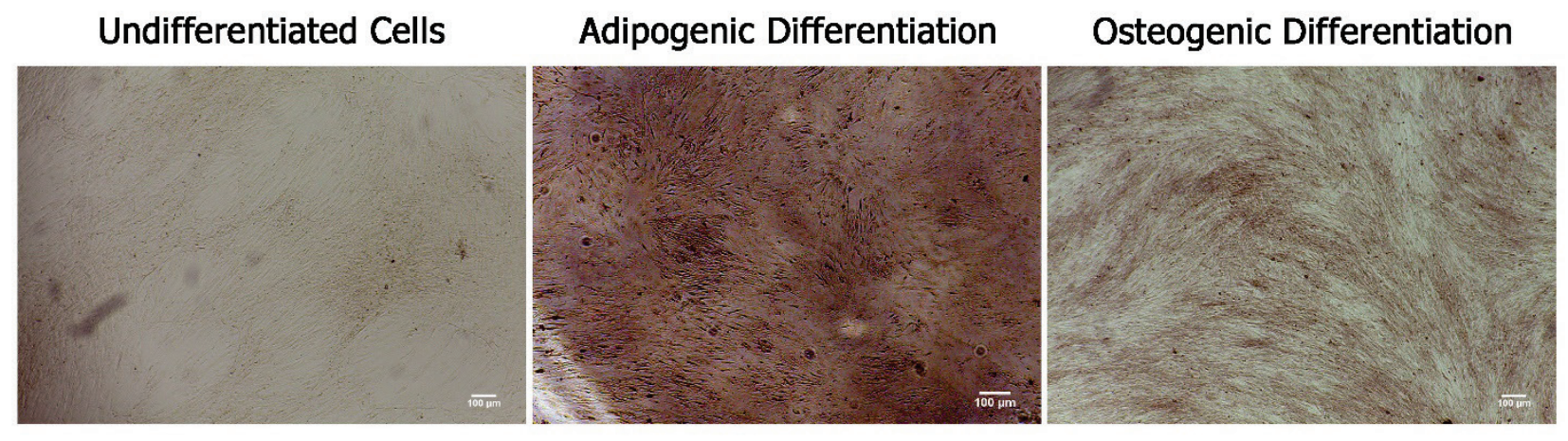

Fig. 1. Differentiation of skin stem cells cultured in a specific adipogenic or osteogenic medium for 21 days. Undifferentiated cells are cultured in basic growing medium. Images are representative of three different experiments. Scale bar $=100 \mu \mathrm{m}$.
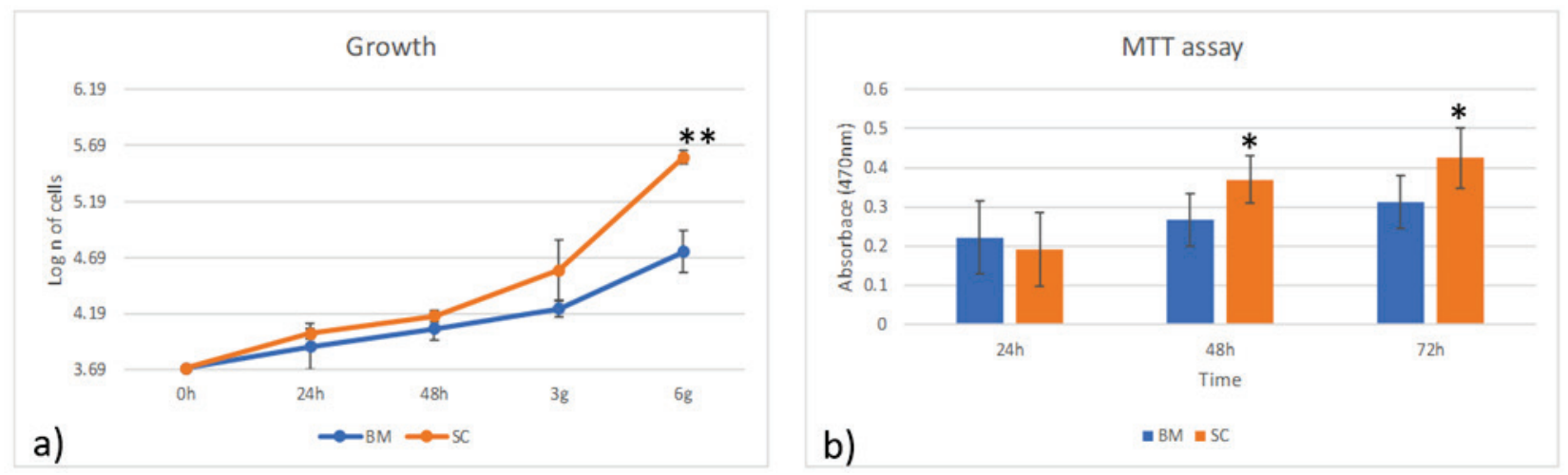

Fig. 2. Growth curve and MTT assay. Statistics are calculated with Anova test ( $P$-value $>0.05)$

In the past both stem cells and transit-amplifying keratinocytes were used to regenerate the epidermidis, being capable to form the epithelium. Nonetheless stem cells results a more suitable source of elements for skin regeneration, than the keratinocytes progenitor's population (Charruyer and Ghadially 2009). The above described protocol allows a rapid and high-yield isolation of stem cells from skin avoiding the use of enzymatic digestion, significantly affecting stem cell properties and viability (Bianchi et al. 2013, Maioli et al. 2013). MTT assay and Growth curve show that the presence of SC-medium significantly enhance cell propagation, also increasing their metabolic activity.

Here we describe a novel highly efficient method to isolate stem cells from skin biopsies without the need of enzymatic digestion. Moreover, we also highlight that this novel medium allows culturing of stem cells preserving their stemness, increasing their viability, and thus optimizing the experimental design. The combination of the SC-medium together with our isolation and culturing method represent a new technique suitable to develop novel strategies for skin regeneration.

\section{Conflict of Interest}

There is no conflict of interest

\section{Acknowledgments}

The study was supported by the project PON-MIUR "Myrtus and its wasting materials as a source of antioxidants: from food to cosmesis", by the Internal 
Grant Agency of the Ministry of Health of the Czech Republic (16-29680A, 17-32285A and 16-28637A) by the Ministry of Education, Youth and Sports within
National Sustainability Programme I, project No. LO1605 and EU COST Project BIONECA action CA1622.

\section{References}

BALZANO F, BELLU E, BASOLI V, DEI GIUDICI S, SANTANIELLO S, CRUCIANI S, FACCHIN F, OGGIANO A, CAPOBIANCO G, DESSOLE F, VENTURA C, DESSOLE S, MAIOLI M: Lessons from human umbilical cord: gender differences in stem cells from Wharton's jelly. Eur J Obstet Gynecol Reprod Biol 234: 143-148, 2019.

BASOLI V, SANTANIELLO S, CRUCIANI S, GINESU GC, COSSU ML, DELITALA AP, SERRA PA, VENTURA C, MAIOLI M: Melatonin and vitamin D interfere with the adipogenic fate of adipose-derived stem cells. Int $J$ Mol Sci 18: pii: E981, 2017.

BLANPAIN C, FUCHS E: Epidermal homeostasis: a balancing act of stem cells in the skin. Nat Rev Mol Cell Biol 10: 207-217, 2009.

CHARRUYER A, GHADIALLY R: Stem cells and tissue-engineered skin. Skin Pharmacol Physiol 22: 55-62, 2009.

GURTNER GC, WERNER S, BARRANDON Y, LONGAKER MT: Wound repair and regeneration. Nature 453: 314-321, 2008.

JEREMIAS T DA S, MACHADO RG, VISONI SB, PEREIMA MJ, LEONARDI DF, TRENTIN AG: Dermal substitutes support the growth of human skin-derived mesenchymal stromal cells: potential tool for skin regeneration. PLoS One 9: e89542, 2014.

KHAVKIN J, ELLIS DA: Aging skin: histology, physiology, and pathology. Facial Plast Surg Clin North Am 19: 229-234, 2011.

LI L, FUKINGANA-KALABIS M, YU H, XU X, KONG J, LEE JT, HERLEYN M: Human dermal stem cells differentiate into functional epidermal melanocytes. J Cell Sci 123: 853-860, 2010.

MAIOLI M, RINALDI S, SANTANIELLO S, CASTAGNA A, PIGLIARU G, DELITALA A, LOTTI MARGOTTI M, BAGELLA L, FONTANI V, VENTURA C: Anti-senescence efficacy of radio-electric asymmetric conveyer technology. Age (Dordr) 36: 9-20, 2014.

MAIOLI M, RINALDI S, PIGLIARU G, SANTANIELLO S, BASOLI V, CASTAGNA A, FONTANI V, VENTURA $\mathrm{C}$ : REAC technology and hyaluron synthase 2, an interesting network to slow down stem cell senescence. Sci Rep 24: 28682, 2016.

MAIOLI M, CONTINI G, SANTANIELLO S, BANDIERA P, PIGLIARU G, SANNA R, RINALDI S, DELITALA AP, MONTELLA A, BAGELLA L, VENTURA C: Amniotic fluid stem cells morph into a cardiovascular lineage: analysis of a chemically induced cardiac and vascular commitment. Drug Des Devel Ther 7: 1063-1073, 2013.

BIANCHI F, MAIOLI M, LEONARDI E, OLIVI E, PASQUINELLI G, VALENTE S, MENDEZ AJ, RICORDI C, RAFFIANI M, TREMOLADA C, VENTURA C: A new nonenzymatic method and device to obtain a fat tissue derivative highly enriched in pericyte-like elements by mild mechanical forces from human lipoaspirates. Cell Transplant 22: 2063-2077, 2013.

MAIOLI M, RINALDI S, SANTANIELLO S, CASTAGNA A, PIGLIARU G, GUALINI S, CAVALLINI C, FONTANI V, VENTURA C: Radio electric conveyed fields directly reprogram human dermal skin fibroblasts toward cardiac, neuronal, and skeletral muscle-like lineages. Cell Transplant 22: 1227-1235, 2013.

MAO AS, MOONEY DJ: Regenerative medicine: Current therapies and future directions. Proc Natl Acad Sci U S A 112: 14452-14459, 2015.

QUAN T, FISHER GJ: Role of age-associated alterations of the dermal extracellular matrix microenvironment in human skin aging: a mini-review. Gerontology 61: 427-434, 2015.

YOUSEF H, VARCALLO M: Physiology, Thermal Regulation. StatPearls [Internet]. Treasure Island (FL): StatPearls Publishing; 2019. 